\title{
PERFORMANCES OF DIAGNOSTIC METHODS IN GASTROESOPHAGEAL REFLUX DISEASE
}

\author{
Elena-Roxana Săraru, Răzvan Peagu, Ana-Maria Călin-Necula, Alexandru Moldoveanu, \\ Carmen Fierbinteanu-Braticevici \\ Emergency University Hospital, Gastroenterology Department, Bucharest
}

\begin{abstract}
Gastroesophageal reflux disease (GERD) is one of the most common chronic gastrointestinal ailments worldwide, with a high prevalence and extremely costly diagnostic and therapeutic management. A hygienic-dietary regimen, accompanied by weight loss, are important factors for improving the symptoms of reflux disease. Various ways of correct diagnosis and for therapeutic management have been attempted over the years, of which the most widely used diagnostic method is empirical therapy with proton pump inhibitors. Also, questionnaires, upper digestive endoscopy with biopsies, barium radiography, ambulatory monitoring of esophageal $\mathrm{pH}, \mathrm{pH}$-impedance and esophageal manometry are widely used. Upper gastrointestinal endoscopy has a good specificity, but a low sensitivity for GERD. Also, the GERQ questionnaire has a good sensitivity and specificity in the accuracy of GERD diagnostic. Barium swallow use belongs to the past, and is recommended mostly for the detection of anatomical anomalies and not for the diagnosis of reflux disease. 24-hour ambulatory monitoring of esophageal $\mathrm{pH}$ is the study of choice to confirm the diagnosis of reflux disease in patients without endoscopic modifications suggestive of GERD. The association of impedance to esophageal $\mathrm{pH}$ monitoring is the gold standard for diagnosing GERD, making it possible to differentiate between acid reflux, weakly acid and non-acid episodes, and is also useful for diagnosing other conditions that mimic the GERD's clinical symptoms.
\end{abstract}

Key words: gastroesophageal reflux disease, proton pump inhibitors, upper digestive endoscopy, GERQ questionnaire, ambulatory monitoring of esophageal $\mathrm{pH}$.

\section{Rezumat}

Boala de reflux gastroesofagian (BRGE) este una dintre cele mai frecvente afecțiuni cronice gastrointestinale la nivel mondial, având o prevalență crescută și costuri extrem de ridicate ale managementului diagnostic și terapeutic. Regimul igieno-dietetic însoțit de scăderea ponderală reprezintă factori importanți pentru îmbunătățirea simptomatologiei bolii de reflux. 


\section{General Reviews}

De-a lungul anilor s-au încercat diferite modalități pentru diagnosticarea corectă și pentru managementul terapeutic, printre care cea mai utilizată metodă de diagnosticare este terapia empirică cu inhibitori de pompă de protoni. De asemenea, mai sunt utilizate chestionarele, endoscopia digestivă superioară cu biopsii, radiografia cu bariu, monitorizarea ambulatorie a pH-ului esofagian, impedanța-pH și manometria esofagiană.

Tranzitul baritat a devenit de domeniul istoric, utilizarea acestuia fiind mai mult recomandată pentru detectarea anomaliilor anatomice și nu pentru diagnosticarea bolii de reflux. De asemenea, chestionarul GERQ are o sensibilitate și specificitate bună în acuratețea diagnosticării BRGE. Monitorizarea ambulatorie pe 24 ore a pH-ului esofagian reprezintă o investigație de elecție pentru confirmarea diagnosticului de boală de reflux la pacienții fără modificări endoscopice sugestive pentru BRGE. Asocierea impedanței la monitorizarea $\mathrm{pH}$ ului esofagian reprezintă gold standardul pentru diagnosticarea BRGE, făcând diferențierea între episoadele de reflux acid de cele slab-acide sau non-acide, fiind utilă și pentru diagnosticarea altor afecțiuni ce mimează tabloul clinic al BRGE.

Cuvinte cheie: boala de reflux gastroesofagian, inhibitori de pompă de protoni, endoscopia digestivă superioară, chestionarul GERQ, monitorizarea ambulatorie a pH-ului esofagian. 


\section{INTRODUCTION}

According to the Montreal classification, the gastroesophageal reflux disease (GERD) is defined as "a condition that occurs in the time point when the reflux of the gastric content in the proximal and distal esophagus causes the triggering of symptoms and complications which occur at least twice weekly and which affect daily activity"(1). It represents one of the most common chronic gastrointestinal disorders globally; in USA approximately $40 \%$ of the general population has esophageal symptomatology intermittently, while only $10-20 \%$ of the population complains weekly of symptoms ${ }^{2}$, 3).

The reflux disease has a high global prevalence, estimated at $8 \%-33 \%$, and represents a digestive condition which affects all age groups, and also both genders $^{(4)}$. It is considered one of the most costly conditions among digestive disorders; mostly these costs are due to anti-secretory treatment with proton pump inhibitors (PPIs), and also to complex diagnosis methods; thus costs of 9-10 billion USD/year have been estimated in the USA $A^{(5)}$.

\section{PATHOGENESIS}

The main mechanisms of triggering the reflux disease are related to changes occurred in the gastroesophageal junction, i.e. a transient lower esophageal sphincter relaxation (TLESR), and the insufficient contraction of the lower esophageal sphincter (LES). Also, presence of a morphological anomaly of the gastroesophageal junction such as hiatal hernia can lead to the development of GERD due to the transient relaxation of the LES and its decreased tonus ${ }^{(6,7)}$. In most GERD cases the esophageal motor function is normal ${ }^{(8)}$, but esophageal hypermotility can lead to a delay of the esophageal clearance and therefore to the increased probability of reflux esophagitis $^{(9-11)}$.

According to the Montreal definition, nonerosive reflux disease (NERD) is defined by the presence of symptomatology associated to the typical acid reflux, but without inflammatory changes of the mucosa visible by endoscopy ${ }^{(1)}$. In the USA it was identified that in about $70 \%$ of those who present typical symptoms of gastroesophageal reflux the upper digestive endoscopy showed an esophageal mucosa with normal aspect (NERD), while $40-50 \%$ of these complain of persistent reflux symptoms despite the gastric acid suppression therapy with proton pump inhibitors ${ }^{(12)}$.

Esophageal hypersensitivity is most commonly defined as a perception disorder of heartburn symptoms and retrosternal pain, without the presence of lesions of the esophageal mucosa ${ }^{(13)}$. The Consensus of the American Gastroenterological Association on the reflux disease states that the symptomatology present within the esophageal hypersensitivity is due to reflux episodes, while functional heartburn is not associated with the presence of gastric acid reflux episodes ${ }^{(14)}$.

At the moment the functional heartburn is a rather controversial disorder both from the point of view of the useful diagnostic investigations and from the point of view of pathophysiology. The Rome Committee considers that patients with heartburn but without endoscopic changes of the mucosa visible by endoscopy but responsive to proton pump inhibitor therapy can be included in the class of non-erosive reflux disease, and not in the class of functional heartburn ${ }^{(15)}$. 


\section{CLINICAL DIAGNOSIS}

The reflux disease is a digestive condition with a variable clinical presentation which consists of the presence of typical symptoms of acid reflux, but also atypical manifestations. Typical manifestation within GERD include heartburn and acidic regurgitations, and among the atypical manifestations are chronic cough, laryngitis, bronchial asthma, dysphonia, pharyngodynia, globus, otitis media, chronic sinusitis, dental erosions, sensation of a pharyngeal foreign body ${ }^{(16)}$. The presence of chest pain requires first of all excluding a possible cardiac cause of the symptomatology, as in some cases GERD can cause an angina-like pain ${ }^{(17)}$. Diagnosing the reflux disease is a high-difficulty process and typically is based on the association between clinical presentation, response to gastric acid suppression therapy, and also objective testing via upper digestive endoscopy and ambulatory monitoring of esophageal $\mathrm{pH}$.

\section{DIAGNOSTIC INVESTIGATIONS IN GASTROESOPHAGEAL REFLUX DISEASE}

An adequate clinical history is an important step in issuing a correct diagnosis algorithm of GERD. The associated symptoms and the history of medicinal products are important diagnosis parameters. The hygienic-dietary regimen can bring significant benefits in case of some patients with GERD, i.e. avoiding consistent meals immediately before sleep, elevating the head of the bead, avoiding the ingestion of citrus fruits and other food which increase gastric acidity, besides weight loss which is an important factor for improving the GERD symptomatology ${ }^{(18)}$.

\section{EMPIRICAL THERAPY WITH PPIS}

In case of patients with typical reflux symptomatology, but without alarm symptoms, it is indicated to initiate empirical therapy with proton pump inhibitors in a regular dose of $40 \mathrm{mg} / \mathrm{day}$ for at least 8 weeks. Patients with typical GERD symptoms who are responsive to acid suppression therapy have an indication of evidence which support the diagnosis of reflux disease due to esophageal exposure to acid reflux.

In the same time patients with atypical symptoms or non-cardiac chest pain should also be considered for performing tests of esophageal function before the empirical therapy ${ }^{(19)}$. Generally the empirical study with PPIs is the main therapeutic approach of the symptomatology, as a high rate of improvement of heartburn in erosive esophagitis is estimated, with a sensitivity (Sv) of $78 \%$ and a specificity (Sp) of $54 \%{ }^{(20)}$. The initial response to anti-secretory therapy is clinically evaluated after 4-8 weeks of 
treatment, and treatment failure to a standard PPI dose defines treatmentrefractory reflux disease ${ }^{(14,21)}$. In case of patients with inefficient response to PPIs in standard dose administered and with a normal result at endoscopy and biopsy, it is considered to further perform additional investigations such as esophageal manometry and ambulatory monitoring of esophageal $\mathrm{pH}$ to sustain the diagnosis of GERD or possibly to evaluate an alternative diagnosis which is associated to the reflux symptomatology ${ }^{(14,21)}$.

\section{GERQ QUESTIONNAIRE}

In time, in order to facilitate the diagnosis of the reflux disease, the use of questionnaires was imposed, to evaluate the frequency of symptoms and the quality of life affected by the presence of symptomatology. Compared to the objective evidence of reflux disease using upper digestive endoscopy and by $\mathrm{pH}$ measuring, questionnaires have a $\mathrm{Sv}=70 \%$ and a $S p=67 \%^{(22)}$. The most commonly used questionnaire is GERDQ, which has a good sensitivity and specificity, and it proved useful enough for diagnosis in the management of the reflux disease; an additional advantage is its low cost compared to the use of the other diagnostic procedures such as endoscopy and $\mathrm{pH}$ metry $^{(22)}$. However in the present the management of the reflux disease is based mainly on the presence of the typical manifestations and is periodically updated via the orientation guidelines in the current clinical practice.

\section{UPPER DIGESTIVE ENDOSCOPY}

It is an extremely useful investigation for the inspection of the esophageal and gastric mucosa, with the ability to provide information suggestive for the diagnosis of structural and mucosal anomalies, such as the presence of reflux and reflux esophagitis, areas of intestinal metaplasia characteristic to Barrett's esophagus, strictures and malignities, as a matter of fact also with implications in the therapeutic management ${ }^{(23)}$. Most often it is performed in the time point when no improvement of the esophageal symptomatology is seen following the empirical therapy with PPIs, as this has a limited utility in uncomplicated GERD, due to the fact that approximately $70 \%$ of the endoscopic examinations in GERD are on anti-secretory treatment, and in over $90 \%$ of GERD treated with PPIs endoscopic examinations are negative ${ }^{(24-26)}$.

According to the Porto consensus, endoscopy is indicated in case of therapeutic failure of PPIs, to evaluate the complications of GERD, and to identify the possible diagnosis alternatives whose symptomatology mimics the clinical presentation of GERD ${ }^{(27)}$. Patients with alarm symptoms such as anemia, marked involuntary weight loss, dysphagia, upper digestive hemorrhage, age over 50 years, and a family history of digestive neoplastic diseases require performing emergency upper endoscopy.

As time went by it was found that in the diagnosis of the reflux disease there are some limitations in the use of endoscopy. Erosive reflux disease occurs in less than $30 \%$ of patients with GERD, while most patients are classified with non-erosive reflux disease (NERD). Most esophagites visualized endoscopically are low grade, and Los Angeles A esophagites are non-specific; these are detected in about $7.5 \%$ of asymptomatic cases ${ }^{(28)}$. When diagnosed with accuracy, Los Angeles B esophagitis provides important information for initiating GERD 


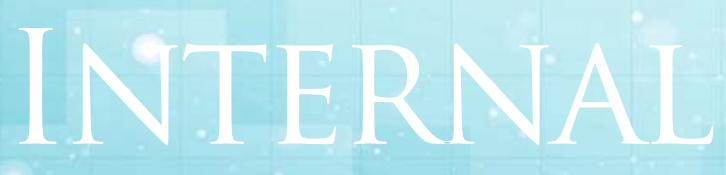

General Reviews

anti-secretory medicinal product therapy; therefore some researchers have stated that in such cases measuring of the esophageal $\mathrm{pH}$ is required before performing a possible antireflux surgery ${ }^{(29)}$. Endoscopy is useful for clinical management, has a good specificity, but a low sensitivity for GERD.

Biopsies may be needed in differentiation of NERD from reflux hypersensitivity, functional heartburn by showing basal cell hyperplasia, dilated intercellular spaces, papillary elongation, presence of intraepithelial inflammatory infiltrate, and sometimes with the presence of erosions or necrosis, histopathological changes suggestive for the initiation of an adequate GERD therapy ${ }^{(30,31)}$.

\section{BARIUM RADIOGRAPHY}

In recent years it became less and less used in current medical practice, especially in the diagnosis of patients with esophageal symptomatology, including with reflux disease, due to its extremely low sensitivity ${ }^{(32)}$. In a study conducted by Belo et al., they sustained the hypothesis that the use of barium in the diagnosis of GERD has no diagnostic value, due to the fact that the presence of reflux is not correlated with the information obtained following an esophageal $\mathrm{pH}$ monitoring test ${ }^{(33)}$. In the study it was noticed that more than half of patients with pathologic gastric reflux included in the study had normal radiologic results, therefore the use of barium swallow continues to be recommended for the identification of anatomic anomalies, and not for highlighting of reflux disease, hiatal hernia, or esophageal strictures.

\section{4-HOUR AMBULATORY MONITORING OF ESOPHAGEAL PH}

It is the only efficient modality in objectifying the existence of a pathologic reflux, it allows direct measurement of esophageal exposure to acid (acid exposure time, AET), it determines the frequency of reflux episodes, and it allows the association between symptoms and reflux episodes. $\mathrm{PH}$-metry is often recommended to confirm the diagnosis of reflux disease in patients without endoscopic modifications suggestive of GERD.

Indications for performing $\mathrm{pH}$-metry include ${ }^{(29-34)}$ :

- patients refractory to the antisecretory therapy with PPIs

- patients who are symptomatic, but without endoscopic evidence of Los Angeles A and B esophagitis

- preoperative evaluation of patients who are to be subjected to antireflux surgery

- postoperative evaluation of patients who continue to present symptoms 
suggestive of GERD post-antireflux surgery

- patients with manifestations atypical for GERD

Contraindications for performing $\mathrm{pH}$-metry are: low patient cooperation, use of anticoagulants or coumarins, coagulopathy, recent gastric surgery, esophageal tumors or ulcers, esophageal varices, esophageal obstructions, maxillofacial traumas, heart disorders $^{(35)}$.

For the correct performance of the ambulatory monitoring of esophageal $\mathrm{pH}$ it is needed to attempt treatment with PPIs or histamine $\mathrm{H} 2$ antagonists with at least 4-7 days before, and a nocturnal food rest at least a few hours before performing the procedure. Acid reflux is considered at a $\mathrm{pH}$ lower than 4 in the distal esophagus. The sensitivity of this test is significantly increased in subjects who discontinued the administration of PPIs. In those patients who continued the anti-secretory treatment and are symptomatic, the $\mathrm{pH}$-metry will provide information only about acid changes, while it cannot detect information about non-acid episodes. A normal pH-metry result in patients on PPIs is suggestive for non-acid reflux or possible esophageal hypersensitivity, but it does not have the ability to differentiate between these $\mathrm{e}^{(36,37)}$. Thus $\mathrm{pH}$-metry continues to be in the present time an investigation of choice for correct diagnosis and for therapeutic management in GERD. Associating impedance to ambulatory monitoring of esophageal $\mathrm{pH}$ increases the sensitivity and specificity of detecting reflux episodes ${ }^{(38,39)}$.

\section{IMPEDANCE-PH}

Is a diagnostic modality that is considered to be the gold standard in diagnosing GERD by monitoring both esophageal impedance and $\mathrm{pH}$, for both anterograde and retrograde detecting of the gastric content in the esophagus, that can be liquid, gas or mixed, and in association with the use of $\mathrm{pH}$-metry it allows to establish the chemical characteristics of the pathologic gastric reflux.

It detects not only an acid $\mathrm{pH}<4$, but also a weakly acid $\mathrm{pH}$ between 4-7, and a non-acid $\mathrm{pH}$ above $7^{(27,40)}$. One of the parameters used in monitoring the esophageal $\mathrm{pH}$ is the AET, which represents the time percentage of the esophageal $\mathrm{pH}$ during which it is lower than 4.0 during its monitoring; it is considered the most reproducible parameter among the measurements for reflux, and it has the ability to differentiate between the physiological reflux and the pathological reflux ${ }^{(27,41)}$. The Lyon consensus states that an AET lower than $4 \%$ can be considered normal, physiological, while an AET $>6 \%$ is defined as abnormal, and values between 4$6 \%$ are considered borderline and undetermined ${ }^{(23,27)}$.

In the Lyon consensus it was proposed to be considered as being abnormal the presence during 24 hours of more than 80 reflux episodes, while a value of 40 or less than 40 reflux episodes to be considered as physiological ${ }^{(27)}$.

The symptom index (SI) is the percentage of symptomatic episodes related to reflux, and a value of this parameter over $50 \%$ indicates the fact that most symptoms experienced by the patient are due to reflux. Symptom association probability (SAP) is a parameter which evaluates the probability of the association of symptoms with reflux episodes, it has a cut-off of $95 \%$, and it is considered positive at a value above 95\%, thus signifying the association between the reflux episodes and the symptomatology 
stated by the patient ${ }^{(27)}$. The DeMeester score was proposed to quantify the exposure to acid of the distal esophagus using six parameters, and a value above 14.72 represents the presence of acid reflux ${ }^{(42,43)}$.

\section{ESOPHAGEAL MANOMETRY}

This investigation is used especially to facilitate the accurate placement of the $\mathrm{pH}$ or impedance-pH catheter, and also to evaluate the esophageal peristalsis and to detect the esophageal motor disorders before antireflux surgery or when there is a symptomatology refractory to the PPI treatment $\mathrm{t}^{(23)}$.

\section{CONCLUSIONS}

The reflux disease continues to be in the present time a chronic digestive disorder commonly encountered globally which requires in most cases the performance of additional investigations to demonstrate the presence of acid reflux episodes, and some of these investigations are extremely costly. Reflux monitoring has a decisive role in the management of patients with symptoms suggestive of GERD, and in association with upper digestive endoscopy it facilitates the establishing the diagnosis of GERD, and also the defining of various phenotypes which can orientate the therapeutic management.

\section{References}

1. Vakil $N$, van Zanten SV, Kahrilas P. et al.- The Montreal Definition and Classification of Gastroesophageal Reflux Disease: A Global EvidenceBased Consensus. The American Journal of Gastroenterology. 2006;101:1900.

2. Dent J, El-Serag HB, Wallander M-A. et al. Epidemiology of gastro-oesophageal reflux disease: a systematic review. Gut. 2005;54(5):710-7.

3. Zagari RM, Fuccio $L$, Wallander $M-A$, et al. Gastrooesophageal reflux symptoms, oesophagitis and Barrett's oesophagus in the general population: the LoianoMonghidoro study. Gut. 2008;57(10):1354-9.

4. El-Serag HB, Sweet S, Winchester CC, et al. Update on the epidemiology of gastro-oesophageal reflux disease: a systematic review. Gut. 2014;63(6):871-80.

5. Shaheen NJ, Hansen RA, Morgan DR, et al. The Burden of Gastrointestinal and Liver Diseases, 2006. The American Journal Of Gastroenterology. 2006;101:2128-38.

6. C Orlando R. Pathophysiology of Gastroesophageal Reflux Disease2008; 42: 584-8 p.

7. Sloan SK, P. J. Impairment of esophageal emptying with hiatal hernia. Gastroenterology. 1991;100:596605.

8. Chan WW, Haroian LR, Gyawali CP. Value of preoperative esophageal function studies before laparoscopic antireflux surgery. Surgical Endoscopy. 2011;25(9):2943-9.

9. Lin $S, K e M, X u$ J, et al. Impaired esophageal emptying in reflux disease. Am J Gastroenterol. 1994;89 (7):1003-6.

10. Bredenoord AJ, Hemmink GJM, Smout AJPM. Relationship between gastro-oesophageal reflux pattern and severity of mucosal damage. Neurogastroenterology \& Motility. 2009;21(8):807-12.

11. Daum C, Sweis $R$, Kaufman E, et al. Failure to respond to physiologic challenge characterizes esophageal motility in erosive gastro-esophageal reflux disease. Neurogastroenterology and motility : the official journal of the European Gastrointestinal Motility 
Society. 2011;23(6):517-e200.

12. Fass R. Erosive esophagitis and nonerosive reflux disease (NERD): comparison of epidemiologic, physiologic, and therapeutic characteristics. Journal of clinical gastroenterology. 2007;41(2):131-7.

13. GC P. Esophageal hypersensitivity. Gastroenterol Hepatol 2010;6:497-500.

14. Kahrilas PJ, Shaheen NJ, Vaezi MF, et al. American Gastroenterological Association Medical Position Statement on the management of gastroesophageal reflux disease. Gastroenterology. 2008;135(4):1383-91, 91.e1-5.

15. de Bortoli N, Martinucci I, Savarino E, et al. Proton pump inhibitor responders who are not confirmed as GERD patients with impedance and $\mathrm{pH}$ monitoring: who are they? Neurogastroenterology and motility : the official journal of the European Gastrointestinal Motility Society. 2014;26(1):28-35.

16. Fass $R$, Achem SR, Harding $S$, et al. Review article: supra-oesophageal manifestations of gastrooesophageal reflux disease and the role of night-time gastro-oesophageal reflux. Alimentary Pharmacology \& Therapeutics. 2004;20(s9):526-38.

17. Galmiche JP, Clouse RE, Balint $A$, et al. Functional esophageal disorders. Gastroenterology. 2006;130(5): 1459-65.

18. Festi D, Scaioli E, Baldi F, et al. Body weight, lifestyle, dietary habits and gastroesophageal reflux disease. World journal of gastroenterology. 2009;15(14):1690701.

19. Aanen MC, Weusten BL, Numans ME, et al. Diagnostic value of the proton pump inhibitor test for gastro-oesophageal reflux disease in primary care. Aliment Pharmacol Ther. 2006;24(9):1377-84.

20. Numans ME, Lau J, de Wit NJ, et al. Short-term treatment with proton-pump inhibitors as a test for gastroesophageal reflux disease: a meta-analysis of diagnostic test characteristics. Annals of internal medicine. 2004; 140(7): 518-27.

21. Hershcovici T, Fass R. An algorithm for diagnosis and treatment of refractory GERD. Best practice \& research Clinical gastroenterology. 2010;24(6):923-36.

22. Dent J, Vakil $N$, Jones $R$, et al. Accuracy of the diagnosis of GORD by questionnaire, physicians and a trial of proton pump inhibitor treatment: the Diamond Study. Gut. 2010;59(6):714-21.

23. Gyawali CP, Kahrilas PJ, Savarino E, et al. Modern diagnosis of GERD: the Lyon Consensus. 2018;67(7):1351-62.

24. Kramer JR, Shakhatreh $M H, N a i k A D$, et al. Use and yield of endoscopy in patients with uncomplicated gastroesophageal reflux disorder. Annals of internal medicine. 2014;174(3):462-5.
25. Savarino E, Yadlapati $R$, Tutuian $R$, et al. The role of nonacid reflux in NERD: lessons learned from impedance-pH monitoring in 150 patients off therapy. Am. J. Gastroenterol. 103: 268593.

26. Savarino E, de Bortoli N, De Cassan C, et al. The natural history of gastro-esophageal reflux disease: a comprehensive review. Diseases of the esophagus: official journal of the International Society for Diseases of the Esophagus. 2017;30(2):1-9.

27. Roman S, Gyawali CP, Savarino E, et al. Ambulatory reflux monitoring for diagnosis of gastro-esophageal reflux disease: Update of the Porto consensus and recommendations from an international consensus group. Neurogastroenterol Motil 2017;29(10):1-15.

28. Takashima T, Iwakiri R, Sakata $Y$, et al. Endoscopic Reflux Esophagitis and Helicobacter pylori Infection in Young Healthy Japanese Volunteers. Digestion. 2012;86(1):55-8.

29. Jobe BA, Richter JE, Hoppo T, et al. Preoperative diagnostic workup before antireflux surgery: an evidence and experience-based consensus of the Esophageal Diagnostic Advisory Panel. J Am Coll Surg. 2013;217(4):586-97.

30. Savarino E, Zentilin P, Mastracci L, et al. Microscopic esophagitis distinguishes patients with non-erosive reflux disease from those with functional heartburn. J Gastroenterol. 2013;48(4):473-82.

31. Kandulski A, Jechorek D, Caro C, et al. Histomorphological differentiation of non-erosive reflux disease and functional heartburn in patients with PPIrefractory heartburn. Alimentary Pharmacology \& Therapeutics. 2013;38(6):643-51.

32. Cesario S, Scida S, Miraglia C, et al. Diagnosis of GERD in typical and atypical manifestations. Acta Biomed 2018; Vol. 89, Supplement 8: 33-39.

33. Bello B, Zoccali M, Gullo R, Allaix ME, Herbella FA, Gasparaitis $A$, et al. Gastroesophageal reflux disease and antireflux surgery-what is the proper preoperative work-up? Journal of gastrointestinal surgery : official journal of the Society for Surgery of the Alimentary Tract. 2013;17(1):14-20; discussion $p$.

34. Katz PO, Gerson LB, Vela MF. Guidelines for the diagnosis and management of gastroesophageal reflux disease. Am J Gastroenterol. 2013;108(3):308-28; quiz 29.

35. American Gastroenterological Association medical position statement: guidelines on the use of esophageal $\mathrm{pH}$ recording. Gastroenterol Clin North Am 1996;110(6):1981.

36. Bashashati $M$, Hejazi RA, Andrews $C N$, et al. Gastroesophageal reflux symptoms not responding to proton pump inhibitor: GERD, NERD, NARD, esophageal hypersensitivity or dyspepsia? Canadian journal of 


\section{I}

General Reviews

gastroenterology \& hepatology. 2014;28(6):335-41.

37. Bashashati M, Andrews CN. Functional studies of the gastrointestinal tract in adult surgical clinics: when do they help? International journal of surgery (London, England). 2012;10(6):280-4.

38. Zerbib F, Roman S, Ropert A, et al. Esophageal $\mathrm{pH}$ impedance monitoring and symptom analysis in GERD: a study in patients off and on therapy. Am J Gastroenterol. 2006;101(9):1956-63.

39. Savarino E, Marabotto E, Zentilin P, et al. The added value of impedance-pH monitoring to Rome III criteria in distinguishing functional heartburn from non-erosive reflux disease. Dig Liver Dis. 2011;43(7):542-7.

40. Sifrim D, Fornari F. Esophageal impedance-pH monitoring. Digestive and Liver Disease 40(3). 2008;40:161-6.

41. Frazzoni $M$, de Bortoli $N$, Frazzoni $L$, et al. Impedance-pH Monitoring for Diagnosis of Reflux Disease: New Perspectives. Digestive diseases and sciences. 2017;62(8):1881-9.

42. Pohl D, Tutuian R. Reflux monitoring: pH-metry, Bilitec and oesophageal impedance measurements. Best practice \& research Clinical gastroenterology. 2009;23(3):299-311.

43. Johnsson $F$, Joelsson B, Isberg PE. Ambulatory 24 hour intraesophageal $\mathrm{pH}$-monitoring in the diagnosis of gastroesophageal reflux disease. Gut. 1987; 28(9): 1145-50. 